\title{
ОСОБЛИВОСТІ ПРОФЕСІЙНОГО ВИБОРУ СТУДЕНТІВ-ПРОВІЗОРІВ
}

\author{
А. Я. Велика, О. О. Перепелиця \\ Вищий державний навчальний заклад України “Буковинський державний \\ медичний університет”
}

\section{FEATURES OF STUDENTS-PHARMACISTS’ PROFESSIONAL CHOICE}

\author{
A. Ya. Velyka, O. O. Perepelytsia \\ Bukovynian State Medical University
}

\begin{abstract}
У статті висвітлено чинники професійного самовизначення студентів-провізорів на етапі професійного навчання. Пріоритетними у виборі професії є соціальні та суб'єктивні чинники. Респонденти у виборі професії зустрілись з проблемами: впливу позиції батьків, необ'рунтованістю вибору професії, недостатньою інформованістю про майбутню діяльність, захопленням зовнішньою стороною професії. Особливістю професійного самовизначення провізорів є низька активність суб'єкта самовизначення. Найадекватнішим підходом до надання допомоги молодій людині у період професійного вибору є психолого-педагогічний супровід, який сприяє створенню внутрішніх умов професійного самовизначення.
\end{abstract}

The article covers the factors of the professional self-determination of students-pharmacists in the phase of professional education. The social and subjective factors have the highest priority in their choice of profession. In their choice of profession the respondents faced some problems: the influence of their parents' position, unsoundness of their profession choice, insufficient information about their future activity, enthusiasm about the appearance of the profession. The most adequate approach to providing assistance to the young person in the period of their professional choice is the psychological and pedagogical support that promotes development of internal conditions of professional self-identification. The low activity of the self-determination subject is the feature of pharmacists' professional self-determination.

Вступ. Проблема підготовки молоді до професійного самовизначення в умовах сучасної ринкової економіки є значущою насамперед для самої молодої людини та її сім'ї. Випускник школи вибирає не просто спеціальність, а в умовах економічної нестабільності - затребувану професію на ринку праці, соціальні гарантії та власне місце в суспільстві. Більшість випускників шкіл недостатньо орієнтується в наукових засадах професійного самовизначення, їм важко розібратися щодо відповідності своїх індивідуально-типологічних характеристик вимогам професій, які вони обирають.

Проблема професійного самовизначення залишається актуальною для молодих людей і після вступу до ВНЗ, в яких ще відбувається формування відповідних якостей у зв'язку з обраним професійним спрямуванням, прийняття вимог майбутньої професії та усвідомлення свого місця в структурі професійної діяльності. Для частини студентівпершокурсників у результаті неусвідомленого професійного вибору виникають внутрішні сумніви, переживання через нереалізовані здібності, від-

(c) А. Я. Велика, О. О. Перепелиця чуття невідповідності обраному профілю діяльності i, як наслідок, виникає стан незадоволеності обраною спеціальністю, який впливає на подальшу успішність студента, його професійну мотивацію.

Проблема професійного самовизначення на етапі професійного навчання у ВНЗ $є$ комплексною, тому її досліджують фахівці різних спрямувань [1-4]. Зацікавленість цією проблемою обумовлена інтересом вищих навчальних закладів до професійного самовизначення особистості студента на етапі професійного навчання, що обгрунтовує актуальність статті.

Мета роботи - визначити чинники професійного вибору студентів-першокурсників за обраною спеціальністю провізора на етапі професійного навчання.

Основна частина. Проведено анкетування 439 студентів перших курсів фармацевтичного факультету ВДНЗУ БДМУ 2012-2016 років навчання. Опитувальник, розроблений С. О. Пакуліною, С. М. Кетько [5], охоплює питання, пов'язані 3 професійним вибором студента та його бажанням працювати в майбутньому за спеціальністю. Мате- 
матична та графічна обробка результатів здійснювалась за допомогою програми “Excel”.

Проблеми вибору професії, етапів професійного та особистісного розвитку висвітлювались у працях багатьох вчених та були сформульовані у вигляді теорій професійного розвитку: теорії професійного становлення особистості (Е. Зеєр, В. Кушнір, О. Леонтьєв, О. Сергєєнко та ін.); теорії самовизначення особистості (М. Гінзбург, Є. Головаха, В. Сафін та ін.) та її професійного самовизначення (Г. Кожухар, Г. Костюк, Є. Клімов, М. Пряжніков, П. Шавір та ін.); концепції професійно-педагогічної підготовки студентів (В. Бондар, Н. Кузьміна, О. Кучерявий, О. Мороз, О. Савченко та ін.).

Професійне самовизначення в педагогіці розглядають як процес самопізнання та об'єктивної оцінки особистістю своїх психологічних особливостей, здібностей, можливостей та порівняння наявних професійних якостей із вимогами, які необхідні для опанування певною професійною діяльністю, яка охоплює вибір професії, навчального закладу та пошуку місця роботи [6]. При цьому професійне самовизначення розглядається не тільки як конкретний вибір професії, але і як безперервний процес пошуку сенсу в освоюваній професійній діяльності [3]. Тому вибір професії слід розглядати як один із етапів професійного самовизначення.

У науковій літературі виокремлюють суб'єктивні, об’єктивні і соціальні чинники вибору професії [7]. До суб'єктивних належать пізнавальні та професійні інтереси, нахили, здібності, темперамент, характер особи. До об'єктивних чинників відносять рівень підготовки, стан здоров'я, поінформованість про світ професій. До соціальних - освітній рівень батьків, їх соціальний статус, соціальне оточення, умови проживання тощо. Важливими чинниками, що впливають на вибір професії, є мотиви професійної діяльності, життєві цінності індивіда, минулий досвід, уявлення про майбутнє, які приводять до розвитку відповідних здібностей, стимулюють до здійснення вчинків. Крім того, ряд вчених підкреслює значення загальної активності, самооцінки, впевненості в досягненні успіху, рівня сформованості свідомої психічної саморегуляції [7].

Результати аналізу анкет першокурсників свідчать, що основними причинами вибору спеціальності провізора $є$ бажання стати професіоналом та престиж цієї професії (рис. 1). Такий чинник вибору професії, як висока сплачуваність праці, $€$ пріоритетним лише для 12,5 \% респондентів. Решта чинників становлять менше $10 \%$.

Отже, провідними мотивами професійного самовизначення студентів-провізорів $є$ престиж вищої освіти, престиж професії, тобто потреба у визнанні, i менш значущою $€$ можливість розкриття своїх здібностей та потреби ринку праці.

Загальноосвітній навчальний заклад повинен готувати старших школярів до вибору професійної діяльності, при цьому важливим є психологічний аналіз професії та оцінка психофізіологічних властивостей і якостей учнів з урахуванням проб їх сил в обраній діяльності [8]. Цю діагностику повинні проводити в школі психологи. Серед опитаних про світ професій вказали на профорієнтацію на уроках $31 \%$ опитаних. Самостійно цікавились інформацією про професію у довідниках навчальних закладів та періодичній пресі $41 \%$ опитаних. Отже, результати тестування свідчать про низьку інформованість школярів про світ професій та недостатню профорієнтаційну роботу в школах. Тому молодим людям доводилося шукати інформацію самостійно і стихійно.

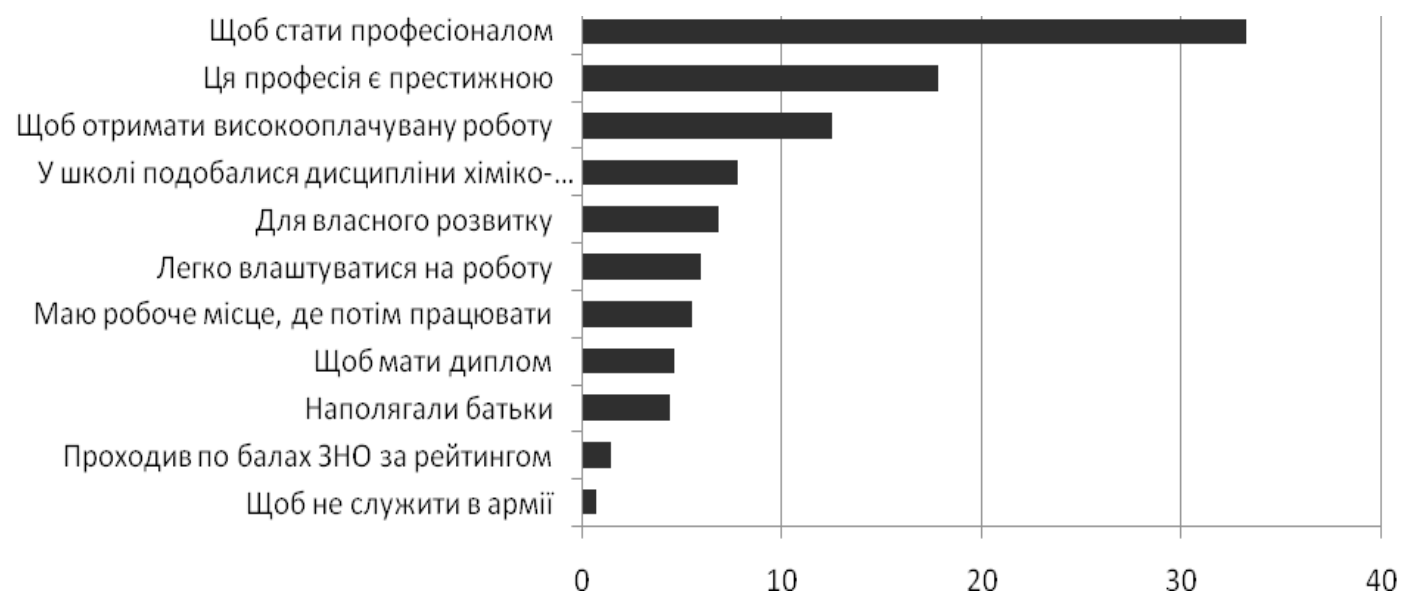

Рис. 1. Розподіл (\%) результатів опитування студентів щодо причин обрання професії провізора. 
На думку Є. Берна, процес вибору професії пояснюється сценарієм поведінки, який формується в ранньому дитинстві [9]. Для професійного самовизначення особистості, на думку П. Шавір, необхідно мати адекватність самооцінки, виражені вольові якості, трудовий і життєвий досвід, достатній рівень зрілості, сформованість відповідних психологічних функцій (функції планування та цілепокладання) [10]. Тому не дивно, що вагомий вплив на вибір майбутньої професії належить батькам (60%) (рис. 2). В такій ситуації молода людина перестає бути суб’єктом вибору професії, їй доводиться керуватися можливостями і бажанням батьків. Компетентну фахову допомогу щодо вибору професії одержали у практикуючих провізорів 19,6 \% респондентів, 15,9\% опитаних робили свій вибір самостійно. Лише 2 \%

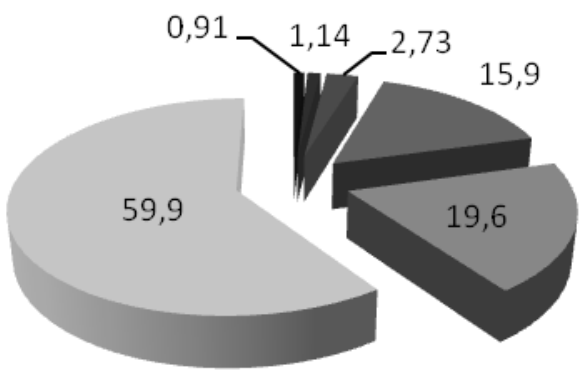

респондентів прислуховувались до порад вчителів та психологів. Отримані результати свідчать про низьку загальну активність майбутніх провізорів при виборі професії, вони продовжують визначатись як суб’ єкти професійного навчання.

Розподіл результатів аналізу анкет студентів щодо питання "Чи знайома Вам робота за обраною спеціальністю?” виявився таким: 41,7 \% опитаним подобається обрана спеціальність, 24,6 \% - мають уявлення про зміст професійної діяльності та 25,5 \% - $з$ роботою ознайомлені. Працювати за спеціальністю провізора мріяли з дитинства 7,06 \% респондентів, а 1,14 \% не уявляють змісту обраної професії. Отже, 25,5 \% опитаних зіставили особистісні якості та реальні вимоги професії, решта захопились зовнішньою стороною професії.

\section{п Психолог школи \\ Учителі \\ Товариші-ровесники \\ Самостійний вибір \\ Фахівці, які працюють за цією професією \\ Батьки}

Рис. 2. Розподіл (\%) результатів опитувань студентів щодо особи, яка вплинула на вибір професії.

Вибираючи професію, 41,5 \% респондентів домінуючим вважають принцип свідомості у виборі професії як такий, що виражає прагнення задовольнити не тільки особисті потреби, але й принести користь суспільству. Принцип відповідності вибраній професії здібностям та інтересам особи обрали 38,5 \% респондентів, стану здоров'я - 2,28 \%. Результати тестування виявили розбіжність між професійним вибором молоді та попитом на ринку праці - вибір професії здійснили з врахуванням потреб регіону в кадрах - 2,96 \% респондентів. Принцип активності як принцип, що характеризує активний пошук професії самою особою, обрали 12,5 \% респондентів. Отже, 82,3 \% респондентів вибір професії здійснили за принципами свідомості та відповідності вибраній професії, не проаналізувавши потреби ринку праці, та проявили низьку активність особистості в реалізації власних інтересів (потреб).

Отже, респонденти у виборі професії зустрілись 3 проблемами: впливу позиції батьків, необгрунтованістю вибору професії, недостатньою інформованістю про майбутню діяльність, захопленням зовнішньою стороною професії. При цьому упевненість 84,5 \% опитаних у правильності свого вибору пояснюється тим, що респонденти 3 допомогою батьків та фахівців зважили на особистісні якості, які відповідають вимогам професії, незважаючи на недостатню інформованість про світ професій. Це черговий раз підтверджує, що найадекватнішим підходом до надання допомоги молодій людині у період професійного вибору є психолого-педагогічний супровід, який сприяє створенню внутрішніх умов професійного самовизначення.

Отримані результати узгоджуються з поглядами засновника науково-психологічного підходу до проблеми професійного становлення особистості Ф. Парсонс (1908), який стверджував, що кожній професії відповідає свій тип особистості, а успішність людини у професійній діяльності залежить від ступеня відповідності індивідуальних якостей особистості вимогам професії. Тобто саме особистісні якості (риси характеру, особливості мислення та сприйняття світу, фізичне здоров’я) визначають професію, якою може займатися людина. 
Отже, головним мотивом вибору професії провізора серед студентів-першокурсників $є$ престиж вищої освіти, престиж професії та можливість отримати високооплачувану роботу. Студенти, обираючи спеціальність, мало інформовані про майбутню професійну діяльність, вибір переважно зумовлений захопленням зовнішньою стороною професії. Усвідомлене власне рішення щодо вибору професії здійснила п’ята частина опитаних, решта виявили пасивність особистості, про яку свідчить залежність особи від обставин, ситуації та цілей, здебільшого, їх батьків. Навіть після вступу до вищого навчального закладу частина молодих людей професійно не визначилась.

\section{Список літератури}

1. Бибрих Р. Р. Особенности мотивации и целеобразования в учебной деятельности студентов младших курсов / Р. Р. Бибрих, И. А. Васильева // Вестник МГУ. Серия 14: Психология. - 1987. - № 2. - С. 78-89.

2. Зеер Э. Ф. Психология профессий : учеб. пособие для студ. вузов / Э. Ф. Зеер. - 2-е изд., перераб. и доп. Екатеринбург : Деловая книга, 2003. - 336 с.

3. Шаповаленко И. В. Возрастная психология (Психология развития и возрастная психология) / И. В. Шаповаленко. - М. : Гардарики, 2005. - 349 с.

4. Щербакова I. М. Актуальні питання професійного самовизначення старшокласників в умовах соціальноекономічної трансформації суспільства / I. М. Щербакова, Н. В. Макаренко // Педагогічні науки: теорія, історія, інноваційні технології. - 2012. - № 8 (26). - С. 213-217.

5. Професійна діагностика / упоряд. Т. Гончаренко. K., 2004. -120 c.
Висновки. Пріоритетними чинниками професійного вибору майбутніх провізорів є: позиція сім'ї, престижність професії, престиж вищої освіти, високооплачувана робота, відповідність своїх інтересів і здібностей обраній спеціальності. Особливостями професійного самовизначення провізорів є низька активність суб'єкта самовизначення.

Перспективними напрямками дослідження порушеної проблеми є визначення особливостей професійного самовизначення майбутніх провізорів старших курсів фармацевтичного факультету університету.

6. Гудименко К. М. Професійне самовизначення старшокласників як психолого-педагогічна проблема / К. М. Гудименко // Педагогічні науки: теорія, історія, інноваційні технології. - 2015. - № 2 (46). - С. 227-232.

7. Климов Е. А. Психология профессионального самоопределения / Е. А. Климов. - М. : Академия, 2004. 304 с.

8. Хомюк I. В. Професійна мотивація як засіб забезпечення професійної мобільності / I. В. Хомюк // Педагогічні науки: теорія, історія, інноваційні технології. 2011. - № 4-5 (14-15). - С. 305-313.

9. Френкин Р. Мотивация поведения: биологические, когнитивные и социальные аспекты / Р. Френкин. - СПб. : Питер, 2003. - 650 с.

10. Шавир П. А. Психология профессионального самоопределения в ранней юности / П. А. Шавир. - М. : Педагогика, 1981. - 96 с. 